\title{
Cross dialect ambiguities of epenthesis
}

\author{
Angeliki Malikouti-Drachman \\ University of Salzburg, Austria
}

\begin{abstract}
In this article, I discuss some cases of cross-dialect ambiguous interpretations of epenthesis as found in the literature, and propose possible alternative interpretations. I confine myself largely to the hiatus cases of $\mathrm{Cri} / \mathrm{eV}$ sequences, that is, a disyllabic domain embracing, for example, the two final consonants $(\mathrm{C} r$-) of a stem and a disyllabic affix $(i / e \mathrm{~V})$. Such cases are found in mor-

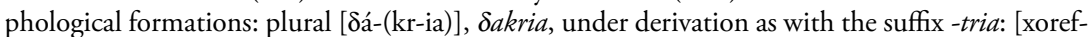
(tr-ia)] xoréftria, or in simple words like kréas, ávrio. I propose that two main factors lead to these ambiguities: the preferred position of the epenthesis inside this disyllabic domain, and the strategy used to resolve the hiatus involved - that is either epenthesis (vocalic or consonantal) or glide- $i$ formation. A further possible factor is interference from prosody and morphology. It is shown that an analysis taking the above factors into account can resolve ambiguities and cast light on similarities as well as differences in position of the epenthetic vowel between related dialects.
\end{abstract}

\section{Keywords}

dialect, epenthesis, Greek, hiatus, homorganic glide, position of epenthesis

\section{Introduction}

Part 2 begins with a discussion of the strategies to resolve problems of syllabification and hiatus in the defined domain, and their relation to the causes of ambiguous interpretation. Section 2.1 refers to vocalic epenthesis, and 2.2 to the two types of consonantal epenthesis: the default $\{\gamma\}$ epenthesis and homorganic glide formation. The distinction is supported by their phonological complementarity in the demi-northern dialect of Vourbiani in 2.3, while section 2.4 adds resolution of hiatus by a glide- $i$ formation strategy.

Part 3 discusses individual cases of ambiguous interpretation. Section 3.1 states the proposals and predictions. Section 3.2 explores ambiguous interpretation between vocalic and consonantal epenthesis as reported for the two SE dialects in Cypriot 3.2.1 and Astypalaea 3.2.2. In both dialects the vocalic epenthesis is located at the edges of the defined domain between stem and suffix, thus provoking the ambiguity. In section 3.3, cases of ambiguous interpretation between metathesis and vocalic epenthesis are presented from 
the northern dialects. In 3.3.1 we give some prerequisites for the ambiguity. There follow the cases of Imvros in 3.3.2, Samothraki in 3.3.3, and Saranda Ekklisies in 3.3.4. In the present cases, the epenthetic vowel is located between the last consonants of the stem, forming the first closed syllable of the domain. It is now the coincidence of this position with that of a metathesised vowel which provokes the ambiguity. A possible ambiguity in the dialect of Saranda Ekklisies can be seen as resulting from morphological interference. The article closes with some conclusions. ${ }^{1}$

\section{Resolving problems of syllabification and hiatus}

\subsection{Vocalic epenthesis}

One way of resolving problems of syllabification in Greek is by vocalic epenthesis. Vocalic epenthesis provides a nucleus to primary or derived sequences of unsyllabifiable consonants. It takes the form of a [-low] coronal or central vowel: i.e., $\dot{\mathrm{i}}$ əə (for the two last types of vocalic epenthesis, see further under 3.3.3 below).

i) For vocalic epenthesis in primary cases of unsyllabifiable consonantal sequences, compare:

a) first, synchronic alternations such as aftón aftóne, pézun pézune, which reflect an epenthetic $\{\mathrm{e}\}$ vowel to syllabify a word final coda (-C\#). However, stress alternations in past tenses such as: épezan pézane indicate rather morphologisation of the epenthetic vowel as a part of the verbal ending and not a synchronic phonological epenthesis.

b) an epenthetic $\{i\}$ vowel is also found in sporadic cases from different dialects to resolve a primary $\mathrm{C} 1 \mathrm{C} 2$ coda/onset sequence, as in: atmós > atimós, kapnós > kapinós from Laconia (Newton 1972: 104, Psaltis 1905: 40, Chadzidakis 1905, a.o.).

ii) For derived cases of vocalic epenthesis compare:

a) first, a triconsonantal -Crj- sequence obtained by glide- $i$ formation for avoidance of a Cri/eV hiatus: alétria > *alétrja > alétirja (to be discussed further below under 3.3.3). In contrast to the cases of primary hiatus, which are rather limited, this last case is found in nearly all Greek dialects.

1 Apart from Samothraki, all cases discussed in this article follow the derivational model. Thus the discussions follow the same theoretical framework. 
b) vowel epenthesis in derived consonantal clusters is also found in cases of clusters derived by loss of unstressed $i / u$ vowel as in the Northern dialects, e.g.: Ipaxnil > pax'in', pézun > pézin (Andriotis 1930) (also discussed further below, under 3.3.2).

In both cases of vocalic epenthesis in derived consonantal clusters (II a, b), since an $i$-vowel is involved — an underlying /i/ or an epenthetic \{i\}—ambiguities may be expected between epenthesis and metathesis. Thus, cases like ayérus for árrios, alétirja for alétria, tirjá for tría in the north Samothraki dialect are accounted for in Topindzi (2006), Topindzi \& Van Oostendorp (2009) as metathesis of the vowel $/ \mathrm{i} /$, whereas in Malikouti-Drachman \& Drachman (2009) they are treated as vocalic-\{i\} epenthesis (to be further discussed below, under 3.3.3).

\subsection{Consonantal epenthesis}

Consonantal epenthesis is used to avoid primary or derived vocalic hiatus by providing a missing onset. It has two forms: 1 ) a default consonant, usually $\{\gamma\}$ for Greek, or 2) a glide homorganic to the first high vowel /i, u/ of the vocalic sequence. Both types of consonantal epenthesis are used in primary or derived cases of vocalic hiatus.

i) The consonantal epenthesis, as default, is a velar $\{\gamma\}$, which, depending on the context, surfaces either as a voiced velar continuant $[\gamma]$ before a back vowel, as in: Aeyós for $\theta e o ́ s$, or as a voiced palatal continuant [j] when a front vowel follows, as in ajéras for aéras.

a) consonantal $\{\gamma\}$-epenthesis in primary hiatus is used in cases of unresolved hiatus such as dialectal kléro, akúro for kléo, akúo, layós for laós, leyoníbas for leonídas (Psaltis 1905: 49).

b) $\{\gamma\}$-epenthesis in derived hiatus is proposed for cases of hiatus from the loss of voiced continuants $v, \delta, \gamma$ in the SE dialects, as in the examples: pníro > pnio with $\gamma$-loss and pnijo with $\gamma / j$-epenthesis in Astypalea, or ejó from eqó through eó in Cypriot (Pantelides 1929: 52). (But cf. 3.2.1, 3.2.2 below).

ii) Homorganic glide formation is obtained by spreading of the first high vowel $i / u$ of the vocalic sequence to form the missing onset of the following vowel. The mid-vowels elo may also participate in the spreading, although in Greek homorganic glide is largely confined to the front vowels ile surfacing as a [j] glide.

a) homorganic glide in primary hiatus is proposed for cases of $\mathrm{Cri} / \mathrm{eV}$ hiatus unresolved by the alternative strategy of glide- $i$ formation, 
reported as in árrijus for árrios, in the northern dialect Vourbiani (Anagnostopoulos 1930) kuprijá for kopriá in Saranda Ekklisies (Psaltis 1905) (discussed further below in 2.3, 3.3.4). ${ }^{2}$

b) homorganic glide formation in derived hiatus are cases from $v, \delta$, $\gamma$-loss, mentioned above, with ambiguous interpretation, to be discussed below in 3.2.2.

In both cases of consonantal epenthesis in primary or derived hiatus the output may be a palatal [j] and as expected ambiguities may arise between hiatus resolution by consonantal $\{\gamma\}$ epenthesis or homorganic glide formation both of which may have the [j] output, discussed below in 3.2.2.

What is more, yet a third ambiguity may occur with the alternative strategy of hiatus resolution by glide- $i$ formation of an underlying vowel /i/, which by consonantalisation has a parallel [j] output. Thus in the SE dialect of Astypalaea forms like $\theta i j o ́ s$ are interpreted in Karanastasis (1958) as $\{\gamma\}$-epenthesis, whereas in Newton (1972: 56) as the output of glide- $i$ formation and vocalic epenthesis, as discussed below.

As a final remark notice that vocalic as well as consonantal epenthesis is also used in sandhi between words. For vocalic epenthesis cf. a) with vowel $i$ : en $i$ stráfti for $\delta e n$ astrafti, en i psilónni for Sen psilóni (Cypriot), en i vréxi for $\delta e n$ vréxi (Megisti) b) with vowel e: en e psinnete for $\delta e n$ psinete (Rhodes) (Pantelides 1929: 20). And for consonantal epenthesis, compare $i / j$ epenthesis in the SE dialect Astypalaea (Karanastasis 1958), e.g., o játropos for o ánAropos, and in Vourbiani (Anagnostopoulos 1930: 139); see below in 2.3. This topic is not discussed further here.

\subsection{Support for two types of consonantal epenthesis}

An appeal to homorganic glide formation as a hiatus resolution parallel to that of consonantal default $\{\gamma\}$-epenthesis comes from the ambiguous interpretation between these two alternative strategies in the demi-northern dialect of Vourbiani. ${ }^{3}$

${ }^{2}$ In a parallel way, by homorganic glide formation we can explain cases of word-initial onset formation in parts of northern dialects, e.g. forms like yéxu for éxo, yékama for ékama from Chalkidiki and with the corresponding back glide wólus for ólos from Komotini. Such forms in Phavis (1951) are explained as the result of diphthongisation due to the strong stress of these dialect, whereas in Newton (1972: 29), from whom the reference comes, as "a diphthongisation rule with very little geographical extension, prefixing on to stressed mid vowels a homorganic glide".

3 Vourbiani belongs to a sub-group of the demi-northern dialects in the Province of Konitsa, where the high unstressed vowels i/u are lost, as in aksa for ákusa, áfk'e for áfike, but mid unstressed elo vowels remain intact: kefál for kefáli, škónome for sikónome. 
According to Anagnostopoulos (1930: 149), one of the main characteristics of

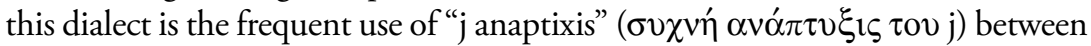
vowels, as in the examples under a) within words, as well as under b) in sandhi:

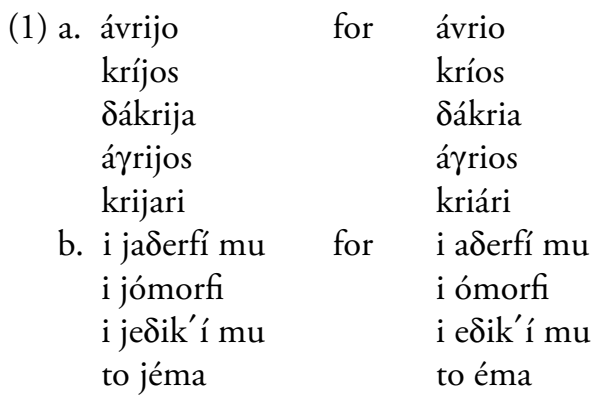

These cases are interpreted by Newton (1972: 56) as consonantal $\{\gamma\}$-epenthesis, since there is no stress shift to justify a resolution by glide- $i$ formation and vocalic- $\{\mathrm{i}\}$ epenthesis. Furthermore, in the same dialect there are parallel forms like $\theta$ erós for $\theta e o s$, justifying the consonantal $[\gamma]$ epenthesis: "the occurrence of kriyo confirms the existence of an epenthesis rule inserting $[\gamma]$ before back vowels except when [i] precedes, otherwise [y]" (ibid. 56). The lack of clarity in the above statement of Newton's supports the distinction between the two types of consonantal epenthesis we propose.

The above data, with [j]-epenthesis, without stress shift, as well as Newton's condition for $\gamma$-epenthesis "except when [i] precedes", indicate resolution of the $\mathrm{Cri} / \mathrm{eV}$ hiatus by spreading the features of the first high vowel. This will provide, heterosyllabically, the missing onset of the following syllable, in other words, a homorganic glide formation. At the same time, the fact that if the first vowel is non-high, hiatus is resolved by consonantal $\gamma$-epenthesis, as in the word $\theta$ erós, indicates that the two strategies of consonantal epenthesis are in complementary distribution in different phonological environments. ${ }^{4}$

The data given in Anagnostopoulos are not enough to allow a complete definition of complementarity in the case of Vourbiani. We may, however, redefine Newton's statement as a case of complementary hiatus resolution by homorganic glide formation when an [i] vowel precedes, as in Crile $\mathrm{V}$, otherwise by consonantal $\{\gamma\}$-epenthesis. What is important in the present cases is the fact that

\footnotetext{
${ }^{4}$ Parallel cases of phonological or even morphological complementarity of consonantal epenthesis are discussed in Rosenthall (1997: 181) with an example from Malay. In that language consonantal epenthesis is a glottal stop when the first vowel is [low] as well as between all prefixes +stem. On the other hand homorganic glides are used after high vowels within morphemes as well as between stems and suffixes.
} 
complementarity between strategies for hiatus resolution, both phonologically as well as morphologically defined, is expected to be found in other languages as well as in the Greek dialects to be discussed. For a complementary distribution of epenthesis morphologically defined, cf. the demi-northern dialect of Saranta Ekklisies in European Turkey (Psaltis 1905), to be discussed below.

\subsection{Resolution of CileV hiatus by glide-i formation}

We saw two strategies resolving the hiatus problem heterosyllabically by splitting the vocalic sequence into two optimal syllables. In contrast, the present strategy resolves the hiatus problem by tautosyllabicity, joining the two vowels into an optimal syllable by gliding the high vowel itself to form the missing onset (semivocalisation). This is the most common strategy of resolving primary hiatus in a $\mathrm{Ci} / \mathrm{eV}$ sequence, and is found in nearly all Greek dialects.

Chadzidakis (1905) already establishes the conditions under which $\mathrm{Ci} / \mathrm{eV}$ hiatus is resolved by glide- $i$ formation as well as the main factors determining the dialect distribution. Further research added to or modified his initial proposals. Newton (1972) codifies the relative processes and proposes the basic rules for resolution of $\mathrm{Ci} / \mathrm{eV}$ sequences in Greek dialects in general. He further defines - in a derivational account - their different ordering to account for dialect variations (Newton 1972: 155ff.). The basic rules are:

Height dissimilation (ibid. 31):

(a) $[\mathrm{e}]>$ [i] in the environment adjacent to [a] or [o], and

(b) $[\mathrm{o}]>\mathrm{u}$ in the environment adjacent to an $[\mathrm{a}]$.

Glide formation (ibid. 32): a high vowel converts to its corresponding glide in the environment before and after a vowel, any stress which it bears being transferred to this vowel.

Manner dissimilation: this rule, which forbids the same manner of articulation in a $\mathrm{C}_{1} \mathrm{C}_{2}$ cluster, consists of three parts 5 according to the voice-value and the type of the consonants involved, and holds in different dialect areas (ibid. 106-109).

\footnotetext{
5 The three parts of Manner dissimilation are defined as follows: If $\mathrm{C}_{2}$ is voiceless, apart from $s$ and $f$, Manner dissimilation is Pan-Greek (Manner Dissimilation Part I). In a more general form, if $r$ is seen as continuous, it is expanded to an $r \theta / r x$ cluster in some dispersed dialects, like Mani, Ikaria and Samos; in the northern islands Lesbos, Samothraki, and Imvros, as well as in Kephalonia, it is limited to $r \theta$ clusters (Part II). In SE dialects, dissimilation applies also in the case of two voiced consonants including an $r+C$ (apart from $s$ and $f$ ) cluster (Part III). Note that in an OT account Manner Dissimilation is an OCP constraint (cf. Drachman \& MalikoutiDrachman (1996), Morelli (1999) Malikouti-Drachman (2006)).
} 
Consonantality: (ibid. 129): a non-vocalic, non-strident, voiced, palatal continuous segment agrees in consonantality and voice with any preceding consonantal segment; if no consonant precedes, it is non-consonantal. This rule accounts for the fact that the glide $[y]$ replaces the feature non-consonantal by consonantal, that is it acquires the audible fricativity of $\left[\gamma^{\prime}\right]$.

\section{Cases of ambiguous interpretation of Epenthesis}

\subsection{Proposals to account for the ambiguities.}

Two proposals can be made to account for ambiguous interpretations. First, in some cases of $\mathrm{CrileV}$ hiatus ambiguity as well as contradictions may be resolved if instead of hiatus resolution by glide- $i$ formation we appeal to the alternative strategy of epenthesis by homorganic glide formation (as proposed in section 3.2).

My second proposal is that ambiguous interpretations are related to the preferred position of the epenthetic vowel. Depending on the way the epenthetic vowel is located inside the disyllabic domain defined above, ambiguity may arise either i) as between vocalic and consonantal epenthesis or ii) as between epenthesis and metathesis. Thus, in the first case the epenthetic vowel is aligned at the edge of the stem, forming with its last consonants an open first syllable in the disyllabic domain, e.g. / $\delta a ́ k r-i a />\delta a ́[k r\{i j j a]$. This is illustrated from the two SE dialects Cypriot and Astypalaea. In the second case, the position of vocalic epenthesis is between the two last consonants of the stem, forming a closed first syllable of the domain e.g. / $\delta a k^{\prime} r-i a />\delta a ́[k\{i\} r j a]$ as in the case of the SE dialect Megisti and the Northern dialect Samothraki.

There is a further factor related to the position of epenthesis, which may contribute to its ambiguous interpretation. This is the occurrence of a process between the last consonant of the stem and the semivocalized coronal /i/vowel of the suffix. In such cases depending on its position the presence of an epenthetic vowel may be clear or obscure. Two dialect forms of a plural formation like / $\delta a ́ k r$-ial illustrate this: a) Rhodes $\delta \dot{a}\left(k^{\prime}\{i\} r g^{\prime} a\right)$ vs. b) Cypriot i) $\delta a(k r\{i\} k a)$ ii) $\delta \dot{a}(k r i j a)$.

In the form a) of Rhodes the presence of an epenthetic $\{i\}$ vowel in the first closed syllable of the $\mathrm{Cr} i \mathrm{~V}$ domain is unambiguous. This is because the underlying coronal vowel $/ \mathrm{i} /$ of the suffix, by gliding to $j$ and occlusivisation after the consonant $r$, surfaces clearly as $\left[\mathrm{g}^{\prime}\right]$. Equally unambiguous is the presence of the epenthetic vowel in the (bi) form $\delta \dot{a}[k r\{i\} k a]$ with the characteristic devoicing of $[\mathrm{g}]$ to $[\mathrm{k}]$ in parts of Cypriot, despite the position of the epenthetic 
vowel at the edge of the stem. In contrast, in the corresponding bii) Cypriot form without a process of occlusivisation of $j$ to $\left[\mathrm{g}^{\prime}\right]$, the potential position of the vocalic epenthesis in the stem could lead to ambiguous interpretation, as shown in section 3.2.1 below.

We show schematically, using the same form, our interpretation of Inputs and Outputs in some of the dialects discussed in the literature with ambiguous interpretation of epenthesis. We have taxonomised them according to the position of the epenthesis as we proposed, and the possible presence of processes; note that $(\mathrm{X})$ indicates further processes, \{\} shows epenthesis, [ ] shows grammatical word, and parentheses () show the disyllabic domain as defined above.

\begin{tabular}{|c|c|c|c|c|}
\hline \multirow{4}{*}{ i) } & \multirow{3}{*}{$/ \mathrm{Cri} / \mathrm{eV} />$} & & & 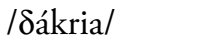 \\
\hline & & $(\mathrm{Cri}\{\mathrm{j}\} V)$ & Cyprus (valley) & 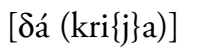 \\
\hline & & $(\mathrm{Cr}\{\mathrm{i}\} \mathrm{XV})$ & Cyprus (Mesarka) & {$[\delta a ́(k r\{i\} k a)]$} \\
\hline & \multirow[t]{2}{*}{ /Cri/eV/ > } & $(\mathrm{Cr}\{\mathrm{i}\} \mathrm{j} \mathrm{V})$ & Astypalaea & 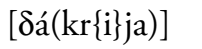 \\
\hline & & $(\mathrm{Cri}\{\mathrm{j}\} \mathrm{V})$ & & {$[\delta a(k r i\{j\} a)]$} \\
\hline \multirow[t]{4}{*}{ ii) } & \multirow{4}{*}{$/ \mathrm{Cri} / \mathrm{eV} />$} & $(\mathrm{C}\{\mathrm{i}\} \mathrm{rjV})$ & Megisti & [ $\left.\delta a ́\left(k^{\prime}\{\mathrm{i}\} \mathrm{rja}\right)\right]$ \\
\hline & & & Samothraki & 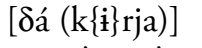 \\
\hline & & $(\mathrm{C}\{\mathrm{i}\} \mathrm{rXV})$ & Maritsa (Rhodos) & {$\left[\delta a^{\prime}\left(k^{\prime}\{i\} r^{\prime} a\right)\right]$} \\
\hline & & & Kalimnos & {$\left[\delta a ́\left(k^{\prime}\{\mathrm{i}\} \mathrm{rza}\right)\right]$} \\
\hline \multirow[t]{3}{*}{ iii) } & \multirow[t]{3}{*}{$\mathrm{Cri} / \mathrm{eV} />$} & $(\mathrm{Cri}\{\mathrm{j}\} \mathrm{V})$ & Vourbiani & 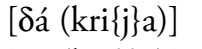 \\
\hline & & & Saranta Ekklisies & 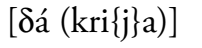 \\
\hline & & & but: ráf-tria & [rá(ftir\{j\}a)] \\
\hline
\end{tabular}

Apart from the intervention of processes, a further diagnostic for disambiguation of epenthesis is stress-shift, which characterises the strategy of hiatus resolution by gliding the underlying vowel /i/ of the suffix, as discussed above. ${ }^{6}$

We confine the discussion to the more problematic case of the di-syllabic domain $\mathrm{Cri} / \mathrm{eV}$, where two consonants precede the hiatus, especially when the second consonant of the sequence is an $r$ : $\mathrm{C}_{1}$ rile $\mathrm{V}$. Since Greek $r$ is not palatalisable, resolution of the hiatus by $i$-gliding leads to an unsyllabifiable triconsonantal cluster $\mathrm{Crj} \mathrm{V}$, which dialects resolve in different ways, as shown below.

\subsection{Ambiguity between vocalic and consonantal epenthesis}

\subsubsection{Cypriot}

To the rules accounting for glide- $i$ formation mentioned above, two more must be added for Cypriot. First, there is devoicing of the output of Manner

\footnotetext{
${ }^{6}$ For diagnostic words and their importance, see Newton (1972: 175ff.).
} 
Dissimilation in Cypriot (Newton 1972: 110-112) and some other SE dialects (such as parts of Rhodes, Kos and Xios): a stop is voiceless except between nasal and vowel or sonant. As an example of devoicing, cf. a form such as /

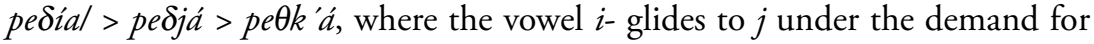
glide formation, and consonantises to a voiceless velar stop under the demand

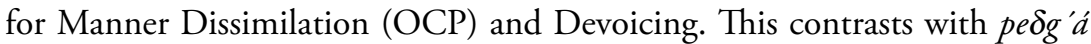
in Rhodes and in other SE dialects, where only Manner Dissimilation (OCP) applies. ${ }^{7}$

The second rule is Velarisation (Newton 1972: 171-172, 175): a voiced non-strident fricative with a non-front point of articulation is velar between a liquid and a back vowel. As an example of velarisation, cf. a form like /xorio/> xorkó vs. xorg'ó in parts of Rhodes, with a further change of the palatal stop to a velar in the $r k^{\prime} \mathrm{V}_{\text {back }}$ sequence.

The occlusivisation of the semivowel to a voiceless stop by Manner Dissimilation and Devoicing is characteristic of Mesarká (Mesaoria). In some other areas of Cyprus a semivowel $j$ is preserved, as discussed below.

Now, in a $(\mathrm{Crile}$ V) hiatus, as in the plural alévria of a form like SMG alévri, with a labial consonant stem-finally, the corresponding Cypriot form shows two alternative outputs: a) aléfka with loss of $r$ as unsyllabifiable, since a labial in Cypriot is allowed in coda position and sonority excludes $r$ from the onset, or b) alérka by $r$-metathesis in coda with subsequent loss of the unsyllabifiable labial, since only one consonant is allowed in coda and the sonority constraint excludes it from onset position. However, if a dental or velar is stem-final, as in aletria or $\delta a ́ k r i a$, instead of metathesis (such consonants being not permitted as a coda) either this consonant is lost or the cluster is resolved with vocalic epenthesis. This enables syllabification of the triconsonantal cluster $\mathrm{C} r k \mathrm{~V}_{\text {back }}$ Thus, for SMG $\delta a$ kria, the Cypriot form is $\delta a$ rka with velar loss or $\delta a . k r i . k a$ with vocalic epenthesis. ${ }^{8}$

Comparison of the segments relevant to hiatus in the input vs. the output

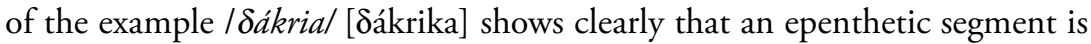
involved. The problem is deciding which one of the two possible epentheses in Greek that represents, consonantal $j / \gamma$ - or vocalic $i$-epenthesis. Both interpretations are found in the literature.

\footnotetext{
${ }^{7}$ In an OT approach this dialect variation is stated as a STRONG ONSET constraint which demands in a $\mathrm{C}_{1} \mathrm{C}_{2} \mathrm{~V}$ sequence that the prevocalic $\mathrm{C}_{2}$ be a voiceless stop (the best type of Onset). For discussion and support from acoustic and perceptual data see Malikouti-Drachman (2001, 2008).

${ }^{8}$ The alternative output a) aléfka or b) alérka depends on the reranking of two constraints, that is LINEARITY dominating SONORITY for form a) aléfka, vs. SONORITY dominating LINEARITY for form b) alérka. (see Malikouti-Drachman 2001).
} 
In the vocalic epenthesis approach, in a form like $\delta a k r\{i\} k a$, the intermediate hypothetical form ${ }^{*} \delta a ́ k r k a$ (instead of an output $\delta a$ rka with $\mathrm{C}_{1}$-loss) surfaces with an epenthetic vowel located at the edges between stem and suffix. This view is supported by Menardos (1969), Newton (1972), Drachman \& Malikouti-Drachman (2008) and others. Notice here the problem of opacity, since the epenthetic vowel breaks down the adjacency of $r$ and palatal $k^{\prime}$ required for velarisation of $k^{\prime}$ to $k$. In a derivational approach the problem is of course solved by rule ordering. Cf. a possible rule ordering' in, e.g., Newton:

\begin{tabular}{|c|c|}
\hline Manner Dissimilation (OCP) & Sákrg'a \\
\hline Devoicing (STRONG ONSET) & Sákrk'a \\
\hline Velarisation & Sákrka \\
\hline Vowel epenthesis & Sákrika \\
\hline
\end{tabular}

Under the consonantal $\gamma / \mathrm{j}$ epenthesis approach, the following derivation is

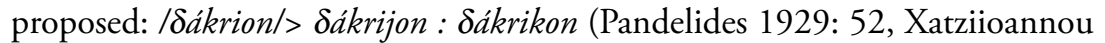
1999: 19, Symeonidis 2006: 183). ${ }^{10}$ This proposal is based on the fact that forms like kriós for krio, kriótis for kriótis, kriás for kréas-quoted without i-glide formation and consonantalisation-are attested from the valley parts of Cyprus ( $\pi \varepsilon \delta \imath v \alpha$ ). Such cases indicate that hiatus of a Crile $\mathrm{V}$ sequence may also be resolved by consonant epenthesis, seen in other SE dialects as in the form krijás from Leros and Kos which is parallel to the Cypriot form krikás (Pandelides 1929: 52).

Further support comes from Cypriot cases with consonantalisation of the

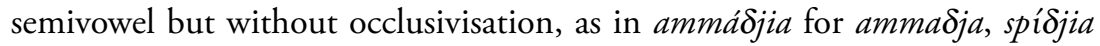
for spidja, which are supposed to be in-between stages. (Xatziioannou 1996: 19, but cf. Menardos 1969: 15).

However, if a $j$-epenthesis is accepted to resolve cases of -Cria hiatus like $\delta \alpha$ krika, two things remain unexplained. First is the occlusivisation to a voice-

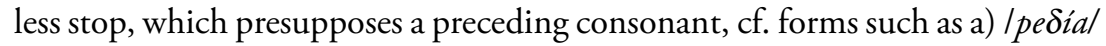
$>p e \theta k^{\prime} a ́$ vs. b) larpárial > arpája. In the first form the consonantalized semivowel $j$ after a consonant occlusivizes to the corresponding palatal stop, but not in b) where no consonant precedes. The second puzzle is the velarisation of the occlusivised palatal $k^{\prime}$ to $k$, which demands adjacency of the relevant

\footnotetext{
9 An OT interpretation is proposed in Drachman \& Malikouti-Drachman 2008, and Malikouti-Drachman 2009.

${ }_{10}$ But notice that the examples which Symeonides (2006) brings up from Medieval Greek to support $j$-epenthesis are interesting but not relevant here. They refer to a -ria sequence and not to a-Cria proposal, while a -ria -to -rjia development has nowhere been suggested. Spellings like $\tau \alpha \chi \omega \rho \gamma i ́ \alpha$ etc. may simply indicate the scribe's effort to render the proper pronunciation.
} 
segments: $r$, palatal stop $k^{\prime}$ and back vowel $\left(r k^{\prime} \mathrm{V}_{\text {back }}\right)$, as already mentioned above.

Furthermore, there are some inconsistencies in the analysis. For cases of $\mathrm{C}_{1} i$ V hiatus with one consonant preceding, Pantelides (1929: 8) accepts occlusivisation of the underlying vowel /i/ of the sequence to $y$ and thence to $k^{\prime}$, as in /xoráfial > xoráfk'a, or xorkón for /xorión/ with further velarisation of -rk'- to $-r k$. However in cases with two consonants preceding the hiatus $\left(\mathrm{C}_{1} \mathrm{C}_{2} \mathrm{iV}\right)$, it is the epenthetic consonant $\gamma / j$ itself which occlusivises to $k$, although without explanation. We may justify this inconsistency and the cause of the ambiguous interpretation, if we consider the parallelisms Pantelidis makes with other SE dialects. Such comparison shows that vocalic epenthesis is placed inside the stem between $\mathrm{C}_{1}$ and $r$ (p. 11): /petriál > petirjá in Megisti, /árria/ > árirza in Kálimnos. Thus an epenthetic vowel located at the end of the stem in a Cypriot form like petrika is excluded. In addition, occlusivisation obtains if only one consonant precedes the vocalic sequence; if two precede, comparison of the Cypriot form krikás with the form krijás from Leros and Kos (pg. 52) indicates that the hiatus is resolved by adding an epenthetic consonant, which in Cypriot is further occlusivised.

Yet both of Pantelides' assumptions are wrong. As we have already seen, the position of the epenthetic vowel may differ between dialects, as in Cypriot and Megisti or Kalimnos. Furthermore the Cypriot form krikás may show not occlusivisation of an intervocalic epenthetic $\gamma / j$ but, in contrast, gliding and occlusivisation of the underlying / $\mathrm{i} /$-vowel of the suffix and vocalic epenthesis (which in Cypriot is located at the edges between stem and suffix), as we proposed.

Finally the form krijás of Leros and Kos as well as in valley areas of Cyprus may indicate not a default consonantal $\gamma / j$ epenthesis (Pantelides 1929: 52, a.o), which is not expected in the SE dialects (see below under 3.2.2), but rather $j$-epenthesis by homorganic glide formation.

To summarize: resolution of $\mathrm{Ci} / \mathrm{eV}$ hiatus is obtained by the strategy of glide- $i$ formation and further occlusivisation for Cypriot in general. But in the $\mathrm{CrileV}$ domain there is variation. In Mesaoria (Mesarká) the same strategy applies, resulting in an unsyllabifiable triconsonantal cluster $\mathrm{C}_{1} r_{2} k_{3} \mathrm{~V}$, a cluster resolved either by loss of $\mathrm{C}_{1}$ or $\mathrm{C}_{2}$ or by vocalic epenthesis located at the edges between stem and suffix. In contrast in valley areas the hiatus either remains unresolved (Pantelidis (1929: 9) or is resolved by homorganic glide formation (vs. the $\gamma / j$ consonantal epenthesis in Pantelidis a. o.)

The Cypriot case shows two things: 1) position of epenthesis at the edges of stem and suffix and 2) resolution of $\mathrm{C}_{1} \mathrm{C}_{2} \mathrm{i} / \mathrm{eV}$ hiatus by complementarity of the two strategies of glide- $i$ formation and homorganic glide 
epenthesis defined areally. A variation on the same conclusions is seen for Astypalaea.

\subsubsection{Astypalaea}

The four basic rules of glide- $i$ formation, listed above, are operative in this dialect, too: Height Dissimilation, Semivocalisation, Manner Dissimilation, and Consonantality, but not the specific Cypriot rule of devoicing responsible for occlusivisation. Thus, whereas forms like érx'ete, ir $\theta e$ surface as érk 'ete, irte with Manner Dissimilation of the voiceless continuant, a form like arrá surfaces as argá and not arká as in Cypriot, that is with only Manner Dissimilation applying to both voiceless as well as voiced segments as in other SE dialects.

Two more of the rules stated by Newton are also operative in the dialect: the Softening rule and also, in contrast to Cypriot, Depalatalisation. (Newton 1972: 155ff. ${ }^{11}$ ) These rules are illustrated in the following two examples from Karanastasis (1958: 67).

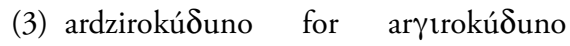
$\operatorname{arko}^{\text {ndzá }} \quad$ for arxondjá

In his description of Astypalaea, Karanastasis (1958: 113-4) mentions cases

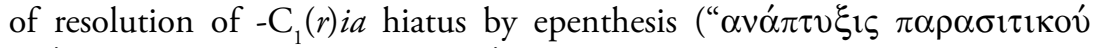

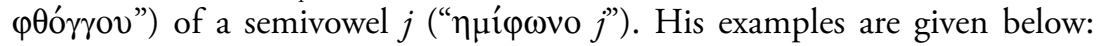
under a) within-word, as well as in sandhi under b) between article + noun, and under c) between words, regardless of the quality of the two vowels. Notice that this last remark holds for all cases of consonantal epenthesis in sandhi (cf. also above, in 2.2).

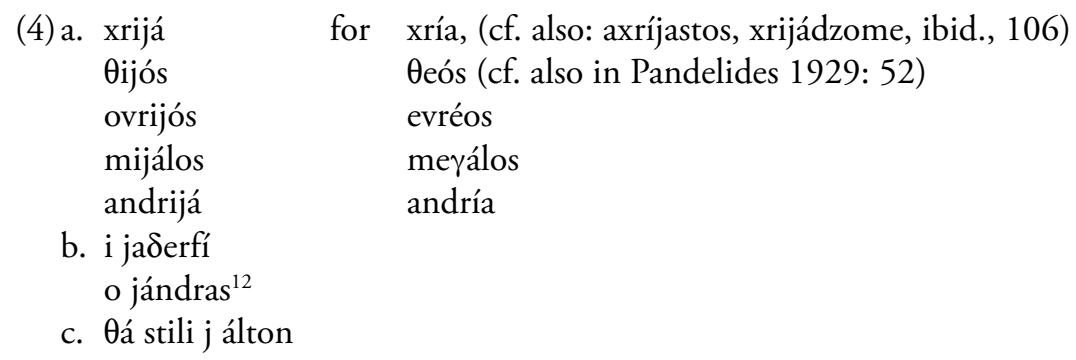

On the other hand Newton (1972: 56) refers to the form $\theta i j o s$ of Karanastasis, which he sees not as the outcome of consonantal $/ \gamma /$ epenthesis, but as vocalic$i$ epenthesis. He parallels the form tijós with the form ovrijós (evréos) of the

\footnotetext{
11 But cf. Dieterich fn. 13 below.

12 cf. also for vocalic epenthesis, ibid: 122 .
} 
dialect, the stress shift in which shows loss of moraicity and thus glide- $i$ formation rather than consonantal $\{\gamma\}$-epenthesis.

Newton's objection to a consonantal epenthesis in forms like $\theta$ ijós, and furthermore in a form like mijálos, rests on the fact that a characteristic of the SE dialects is the intervocalic loss of voiced continuants $v, \gamma, \delta$, whereas the distribution of $\gamma / j$ epenthesis is "throughout the Mainland, Crete, the Ionian isles, and Old Athenian except Maniot. The phenomenon does not occur in the south east." (Newton 1972: 53).

Consequently, in the cases of Karanastasis, the $/ \gamma /$-loss seems to be contradicted if not only by a primary hiatus like $\theta e o$ s, but also by a secondary hiatus provoked by $/ \gamma /$-loss, as in merálos, resolved by consonantal $\gamma / j$ epenthesis. Such a contradiction is seen clearly in the derivation of forms like pnijo in Astypalaea, as proposed by Pantelides (1929: 5): pníro > pnio with $\gamma$-loss, or pnijo with further consonantal $\gamma / j$-epenthesis, that is cases where a $\gamma$ is lost in order to be later substituted by a $j$-epenthesis.

Thus for Newton (1972: 56), the cases of $\gamma / j$-epenthesis of Karanastasis are derived by the general rules of hiatus resolution by glide- $i$ formation: Height dissimilation accounts for the raising of $e / o$ to $i / u$ before a back vowel in both forms, while glide- $i$ formation accounts for the stress shift in ovréos $>$ ovriós $>$ ovrjós and $\theta i o ́ s>\theta j o ́ s$, followed by vocalic $i$ epenthesis:

\begin{tabular}{|c|c|}
\hline Teight dissimilati & $\begin{array}{l}\text { /ovréos/ } \\
\text { ovríos }\end{array}$ \\
\hline lide- $i$ formation & ovrjós \\
\hline$\{\mathrm{i}\}$-epen & ovrijós \\
\hline
\end{tabular}

Thus the question of ambiguous interpretation arises: is the hiatus in e.g. $\mid x r$-ial > [xrijá] resolved as [xri\{j\}á] with consonantal [j]-epenthesis as in Karanastasis, or as $x r\{i\} j a$ with glide- $i$ formation and vocalic $\{\mathrm{i}\}$-epenthesis as in Newton?

The similarity with the Cypriot cases of ambiguous interpretations discussed above, and their relation to the place of the epenthesis, are obvious. As in Cypriot, the position of the vocalic epenthesis in Newton's proposal is at the right edge of the stem (aligned right) before consonantalisation of the underlying vowel /i/ of the suffix -ia; cf. Cypriot $/ \delta a \dot{k} r-i-a />\delta a ́ k r\{i\}-k-a$ and Astypalaea $|x r-i a|>[\operatorname{xr}\{i\}-j-a ́]$. It is this position, where vocalic $\{i\}$-epenthesis and underlying stem-final / $\mathrm{i} /$ coincide, which provokes the ambiguity between consonantal $\{\gamma / \mathrm{j}\}$-epenthesis and vocalic $\{\mathrm{i}\}$-epenthesis.

In Cypriot (Mesarka), the ambiguity in a case like $/ \delta a \dot{k} r-i-a />\delta a ́ k r\{i\} k a$ is resolved by the interference of the two processes, Devoicing and Velarisation, the application of which demands adjacency of the last consonant of the stem 
$-r$-and the semivowel $j$ from underlying /i/. cf. the schema: disyllabic domain $(\mathrm{CriV})>(\mathrm{CrkV}) .>(\mathrm{Cr}\{\mathrm{i}\} \mathrm{kV})$, as above. Thus, the demand for a glide to be next to the last consonant of the stem excludes the possibility of hiatus resolution by consonantal $j$-epenthesis. On the other hand, the occurrence of a parallel form $\delta a k$ rija in other Cypriot areas allows for the possibility of ambiguous interpretation. We thus propose for Cypriot coexistence of the two glide-forming strategies: glide- $i$ and homorganic glide in a complementation determined areally.

For the Astypalaea forms, a parallel indication to $\delta a k r\{i\} k a$ for resolving the ambiguity is the suprasegmental stress shift in e.g. / $x$ r-ial> [xrijá], which shows loss of moraicity of the underlying vowel /i/ of the suffix, and thus its semivocalisation. So, Newton's correlation of stress shift and glide- $i$ formation is justified, as is his derivation of forms with $\mathrm{C}_{1}$ rile $\mathrm{V}$ hiatus: (as discussed above for Cypriot) ovrijós, adrijá, xrijádzome, xrijá and axrijastus.

However, we propose a different account for the form $\theta i j o ́ s$ and other similar examples with $\mathrm{C}_{1} e / i \mathrm{~V}$ hiatus such as mijálos, ójos etc., of Karanastasis. As the parallel derivation of the two forms ovrijós and Bijós given above shows, the intermediate hypothetical form, after glide formation: ${ }^{*}$ ovrjós has a triconsonantal cluster vs. the biconsonantal one of the corresponding form $\theta j$ ós. Thus, whereas vocalic epenthesis is expected in the first case, in the case of the biconsonantal sequence of the latter it is not. Compare for example, a form like / xorió/ with an output of the bisegmental cluster xordzó through further processes of softening and depalatalisation, both of which are blocked by the epenthetic vowel in the trisegmental cluster in ${ }^{*}$ ovrjós $>$ ovr $\{i\} j$ jos. ${ }^{13}$

Furthermore, the output of a derived hiatus in a bisegmental $-\theta j \mathrm{~V}$ - sequence by glide- $i$ formation in Astypalaea undergoes not vocalic epenthesis but

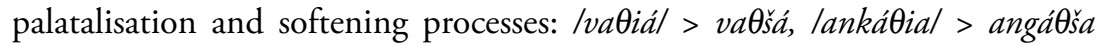
(Pandelides 1929: 8, Karanastasis 1958: 115). The same holds for the other parallel form mijálos for meyálos, where also the output of a $-m j \mathrm{~V}$ - sequence is palatalised $m^{\prime}$ (cf. $m n$ ' $a$ for mía in Karanastasis) and not the bisegmental mijálos.

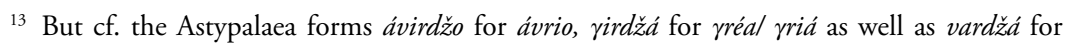
varja in Dieterich (1905: 53), where the position of the epenthetic vowel is inside the stem and thus the softening rule applies, although not the depalatalisation seen in the Karanastasis forms. It is not clear from Dieterich's work how to account for this difference in the position of the epenthetic vowel between data reported in 1905 and those of 1958. One thing is clear. In Dieterich's data - $r i \mathrm{~V}$ - and - $\mathrm{C} r i \mathrm{~V}$ - hiatus have the same output, which differs from that of a primary hiatus as in $\theta i j o ́ s$ or a derived hiatus as in pnijo. In the later data, this similarity of $r i \mathrm{~V}$ and a $\mathrm{Cr} i \mathrm{~V}$ sequence seems to be lost. It is substituted by the opposed similarity of a primary hiatus $\theta i j o ́ s$ or a derived pnijó versus a $\mathrm{C} r i \mathrm{~V}$-sequence. 
My proposal is that we may justify Newton's objection to correlating intervocalic loss of $v, \delta, \gamma$ with consonantal epenthesis if we accept that hiatus in the relative cases $\theta i j o ́ s$, mijálos, etc., is resolved by homorganic glide formation, the outcome of which by spreading and heterosyllabicity coincides with consonantal $\gamma / j$-epenthesis. On the other hand, hiatus in CrileV cases, like ovrijós, etc., are resolved by glide- $i$ formation, as Newton proposed. In other words, my proposal is that, as in Cypriot, in Astypalaea, too, there is complementarity in the application of the two glide-formation strategies, glide- $i$ and homorganic glide formation, however, with the following difference: whereas in Cypriot the complementarity is areally defined, in Astypalaea it is phonologically defined, as indicated above. ${ }^{14}$

\subsection{Ambiguity between Vocalic Epenthesis and Metathesis}

\subsubsection{Some Prerequisites}

We have discussed two cases of ambiguous interpretation between vocalic and consonantal $j$-epenthesis in Cypriot and Astypalaea. In these cases, diagnostic criteria-like processes or stress shift-confirmed resolution of $(\mathrm{Cri} / \mathrm{eV})$ hiatus by vocalic epenthesis, and showed that the epenthetic vowel is aligned at the edges between stem and suffix (i.e. the right edge of the stem and the left edge of the suffix) and thus provokes an ambiguous interpretation.

In the present case of $(\mathrm{Cri} / \mathrm{eV})$ hiatus, the ambiguity is between vocalic or consonantal $(r)$-metathesis and vocalic epenthesis. For this ambiguous interpretation to be possible, certain similarities are required, such as 1) presence of a metathesised, alternatively epenthesised vowel inside the stem, and 2) simultaneous presence of a [j], so that, on the one hand, an underlying vowel can be metathesised, and on the other, a triconsonantal cluster ${ }^{*} \mathrm{Crj}$ can be the basis for a vowel to be epenthesised. This is shown under the schema a) below.

On the other hand, since the epenthetic vowel does not interact with edges (as against the cases of Cypriot and Astypalaea), processes demanding adjacency of the final segment of the stem and the initial one of the suffix are expected. And what is more, such cases show unambiguously that the position of the epenthetic vowel is inside the stem, thus fulfilling the requirement for positional similarity as stated above. The required schema is under b) below (cf. also the schemata in 3.1 above).

${ }^{14}$ For Dosuna (2002: 98), hiatus may reflect the failure of synizesis (i.e. glide formation etc.) to apply, but it may also be the result of dieresis (heterosyllabicity, to be discussed elsewhere). 
a) For an input schema $/(\mathrm{C} r+i / e \mathrm{~V}) /)$ the output is $[\mathrm{Cir}+\mathrm{jV}]$.

b) For an Input schema $/(\mathrm{Cr}+i / e \mathrm{~V}) /$ the output is $[\mathrm{Cir}+\mathrm{XV}]$.

As expected, ambiguous interpretations are possible only in the first case (a).

Before discussing the cases involving ambiguity, we justify the demand for the position of vocalic epenthesis inside the stem with an example from the village Maritsa in Rhodes (Tsopanakis 1940: 67). In the greater part of the island, if the first vowel in the $(\mathrm{Cri} / e \mathrm{~V})$ hiatus is stressed, the stress shifts to the next vowel, without resolution of hiatus by glide- $i$ formation (semivocalisation of the $i) .{ }^{15}$ However in some areas, like Maritsa, resolution of the hiatus by glide- $i$ does apply, followed by the expected processes of Manner Dissimilation applying to $r+$ Voiced continuant $-r j>-r g^{\prime}$ - since Rhodes is a SE dialect-with further vocalic epenthesis to syllabify the triconsonantal cluster. As the examples show, the position of the vocalic epenthesis is inside the stem. Notice that the forms from the capital of Rhodes, in (5), lack vocalic epenthesis.

(5) Maritsa

$\begin{array}{llll}\text { kirg'ós, kirg'ónno } & \text { for } & \text { kríos } & \\ \text { kopirg'á } & \text { for } & \text { kopriá } & \text { koprg'á } \\ \text { tírg'a } & \text { for } & \text { tría } & \text { trg'á } \\ \text { tirg'ánda } & \text { for } & \text { triánda } & \text { trg'anda }\end{array}$

We take now three cases of ambiguity between Epenthesis and Metathesis from the northern dialects.

\subsubsection{Imvros}

The ambiguity in this case comes from unstressed $i / u$ vowel loss word finally under 6a), b) and c), as well as the nucleus of the final syllable of the word under d). If vowel loss results in an unsyllabifiable cluster, its resolution is obtained by vocalic epenthesis, especially word-finally (Andriotis 1930: 149):

$\begin{array}{rll}\text { (6) a. alévir } & \text { for } & \text { alévri } \\ \text { alétir } & & \text { alétri } \\ \text { zmírin } & & \text { zmírni } \\ \text { Sáfin' } & & \text { Sáfni } \\ \text { páxin' } & & \text { páxni } \\ \text { b. áspir } & \text { for } & \text { áspri } \\ \text { agáštir } & & \text { agástri }\end{array}$

15 On this see Dosuna (2002) with an argument for refuting Andriotis' (1930) height dissimilation process. 


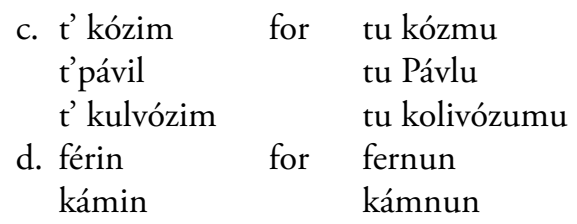

Since vowel epenthesis in Greek is primarily realised as a coronal [i] vowel, an interpretation of the forms under a) and b) above as metathesis of the final underlying vowel /i/ would be a possibility. However, a vowel [i] is also realised in cases where the lost vowel is not an $i$ but an underlying $/ \mathrm{u} /$ as in cases under c) and d), therefore excluding metathesis. However forms under d) raise the possibility of morphological restructuring of the verbal ending, a topic not discussed further here (see further Andriotis 1930: 150).

\subsubsection{Samothraki}

An important feature of this dialect is prevocalic $r$-loss in an Onset position with lengthening of the following vowel. However, an $r$ in coda position remains intact (for the description of the dialect see Katsanis 1996). This is illustrated under $\mathrm{f}$ ) where final $i$ is lost with $r$ surviving as coda as well as in cases $\mathrm{d}$ ) and e) which show the output of resolution of $\mathrm{CrileV}$ hiatus, where again $r$ is in coda position and survives (data are from Katsanis 1996, and see also Topintzi 2006).

\begin{tabular}{|c|c|}
\hline $\mathrm{CrV}_{1} \mathrm{C}$ & vrísi > ví:s' \\
\hline b. $V C C r V>V C C V_{1} V_{1}$, e.g. & aspra >a spa: \\
\hline c. $\mathrm{C}_{\text {velar }} \mathrm{r}$ i/eC $>\mathrm{C}_{\text {velar }}$ i/ว:C, e.g. & $\begin{array}{l}\text { grizos > gi:zus } \\
\text { kríma > ki:ma (vs. kíma > k'íma) } \\
\text { kremnós> kə:mús }\end{array}$ \\
\hline d. $\mathrm{Cri} / \mathrm{eV}>\mathrm{CirjV}$, e.g. & $\begin{array}{l}\text { tria > tirjá } \\
\text { alétria > alétirja }\end{array}$ \\
\hline e. $C_{\text {velar }}$ ri/eV > $C_{\text {velar }} \dot{i} / \partial r j V$, e.g. & 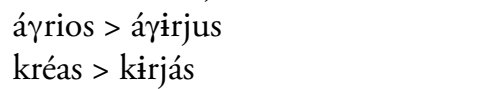 \\
\hline f. $r$ in coda position ${ }^{16}$, e.g. & $\begin{array}{l}\text { fanári > fanár } \\
\text { karpós > karpós }\end{array}$ \\
\hline
\end{tabular}

${ }^{16}$ Topintzis' (2006) analysis is based on Katsanis (1996), where $r$-survival in coda position is a characteristic of contemporary speech of the dialect. Earlier description in Heisenberg (1921) of the speech of 'Hirten' (shepherds) from Samothraki mentions extensive $r$-loss. This view, although disputed by others, is accepted by Andriotis (1930), Newton (1972), and also Katsanis (1996: 49). Malikouti-Drachman and Drachman (2009) support Katsanis' view that $r$-revival in coda position in contemporary speech is in fact an innovation. They compare the differences 
Another interesting feature related to $r$-loss is the variation of the coronal /i/ vowel, which is centralised when lengthened after $r$-loss if it becomes adjacent to a velar consonant, which remains unaffected. Cf. the two forms under c) above: 1) ki:ma for krima with $r$-loss, a centralised vowel and a non-palatalised $k$, vs. 2) / kima/ : [k'íma] with a short front vowel $i$ and palatalisation of the velar consonant. The same remark holds for the front vowel /e/ of the example under c). Cf. also below ${ }^{17}$ for the metathesised vowel in Topintzi \& van Oostendorp (2009).

In an interesting analysis of $r$-loss phenomena in Samothraki (Topintzi 2006, as well as Topintzi \& van Oostendorp 2009) cast in the framework of Optimality Theory, the hiatus sequence $\mathrm{CrileV}$ is resolved by spreading the $i$-vowel to form an onset (homorganic glide) and metathesis of $i$ in the sequence $-r i-$, to an -ir-one. This ensures that "the loss of $r$ in an Onset" is no longer operative. The metathesised coronal $i$-vowel shows the same variation as the front vowels after $r$-loss mentioned above. It is centralised if next to a velar consonant, otherwise remaining a coronal, as the examples under d) and e) above illustrate (kreas $>$ kírjás, árrios > árirjus vs. aletria >aletirja, tría >tirjá).

In Topintzi \& van Oostendorp (2009: 393), the variation of the $i$-vowel is due to a constraint disallowing the spreading of a feature over more than two segments in a disyllabic span. This implies that in the disyllabic hiatus span $\left.\left[\delta a C_{1} \mathrm{ri}_{2} \mathrm{j}_{3} \mathrm{a}\right)\right]$ the three segments - the glide $\mathrm{e}_{3}$, the underlying coronal $i_{2}$ and the velar ${ }_{1}$ - may not share the feature coronal. To obtain this, the glide $j$ retains the acquired coronality, whereas the underlying coronal vowel $i$ is delinked from its underlying feature; it centralises and metathesises next to the velar consonant, the feature of which consequently remains intact as in the above examples (7e, árírjus, kirjás)

The problem is not the way the vowel variation is accounted for. The variation is well motivated and the disyllabic span too, not only for the cases Topintzi and van Oostendorp mention from other languages e.g. Ekegusii or

between present-day Samothraki and Heisenberg's earlier data of the 'Hirten' variant. The main difference is that $r$-in-coda corresponds to a long vowel or a diphthong in the speech of 'Hirten'. Three positions are involved:

1. Word-final e.g. /maxeri/ > max'ér vs. max'éi.

2. Within-word before a derived $\mathrm{j}$ in hiatus, e.g. /maxéria/ > max 'érja vs. max'eija.

3. Within-word in coda position, e.g. /karpós/> karpós vs. kaipós.

They account for these differences in terms of constraints and their re-ranking. Notice that loss of $r$, as well as $l$, is also mentioned in Kretschmer (1905: 159) from Kapi, a small village in Lesvos, as well as in Kontosopoulos (1994: 106), however without further comment.

17 Such a variation is simply mentioned in Kontosopoulos (1994: 107), from Limnos. 
the Greek of Cappadocia (Revithiadou et al. 2006) but also from other parts of Greek phonology, e.g. spontaneous gemination in Cypriot (MalikoutiDrachman 2008 and further references therein).

However, objections have been raised concerning the resolution of the hiatus by metathesis. Malikouti-Drachman \& Drachman (2009) argue that in $\mathrm{CrileV}$ hiatus in Samothraki, as in other Greek dialects, $i$ may be resolved by glide- $i$ formation, and vocalic epenthesis. This approach is needed anyway to account for hiatus in $\mathrm{Ci} / e \mathrm{~V}$ sequences like / luriál > lurjá or $r \mathrm{Ci} / e \mathrm{~V}$ sequences, e.g. Ikarfial > karfiá where there is no trace of an $i$-metathesis at all, and kréas > kirjás with stress shift, which indicates resolution by $i$-gliding. This approach also accounts for the survival of $r$ as shown in the example above: luri luí but luriá> lurjá.

A further difficulty with the metathesis proposal is the phonological and morphological readjustments which the coronal /i/-vowel of the suffix must undergo in order to metathesise. Whereas the glide $j$ retains the acquired feature of coronality, the underlying coronal vowel /i/ itself is delinked from its own feature and becomes part of the stem, thus losing part of its phonological and morphological recoverability, as in the example: $\delta a k_{1} r i_{2} j_{3} a-$ $\left[\delta a\left(k_{1} i_{2}{ }_{2} j_{3} a\right)\right]$.

In contrast, with hiatus resolution by the $i$-gliding strategy there is no need for such readjustments. The glide is the underlying coronal /i/ itself, whereas the epenthetic vowel is unspecified. When adjacent to a velar in the disyllabic span, it centralises as the constraint of Topintzi \& van Oostendorp demands; otherwise it takes its default i-value of a coronal vowel. Its position as the last syllable of the stem contributes to its recoverability, and it is also found in other dialects not sharing $r$-loss.

It seems that in the case of Samothraki the ambiguity between metathesis and epenthesis is constrained to the resolution of $\mathrm{CrileV}$ hiatus. The other cases of $\mathrm{CileV}$ hiatus clearly demand resolution by glide- $i$ formation, since there is no coexistence of an onset [j] and a vowel $-i$, the two prerequisites mentioned above under 3.3.1, to cause an ambiguous interpretation. We may thus at least conclude, provided homorganic glide and metathesis somehow find more support, that maybe Samothraki adds one more case of hiatus resolution by phonological complementarity of the two glide formations: that is, homorganic glide and metathesis in the case of $\mathrm{Cri} / \mathrm{eV}$ hiatus but glide $-i$ in the other hiatus cases.

An interesting case, with some similarities as well as differences from Samothraki is the demi-northern dialect of Saranda Ekklisies. Here, resolution by the two glide formations is clearly an instance of complementarity, which however is morphologically defined in the present case. 


\subsubsection{The demi-northern dialect of Saranta Ekklisies}

In his description of the dialect, Psaltis (1905: 29) defines the resolution of the $-i+\mathrm{V}(a, o, u, e)$ hiatus within a word as follows, distinguishing three cases:

i) Ending within a word:

Ending - $i$ - within a word before a back vowel as well as $e$ becomes a semivowel $-j$, with reference to Chadzidakis (1905: 335). His examples show that morphology is not involved:

(8) in nouns: laoj'á

in neuters: fortjó, siní日jo

in verbs: jeljúme

In other words in these cases, resolution of hiatus is obtained by glide- $i$ formation, as in SMG and many other dialects.

ii) $(\mathrm{C}) \mathrm{Cr}+\mathrm{ia}$ :

However in the case of a sequence $d r, t r, p r, \gamma r$, the vowel $i$ is retained. The

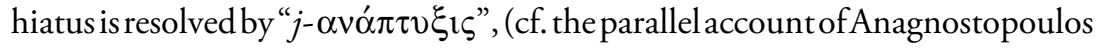
(1930) for Vourbiani discussed above under 2.3).

(9) dr-poxódrija for ipoxóntria

tr- óstrija ostréa

pr-kuprijá kopriá

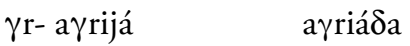

In other words, hiatus in the present cases is resolved by homorganic glide formation.

Notice that, as the examples show, in the first case (i) of $\mathrm{Ci}+\mathrm{V}$, hiatus glide -i-formation applies not only after one consonant, even $r$, but also after two consonants $\mathrm{C}_{1} \mathrm{C}_{2}$ (fortjo, with the $r$, of course, as coda). However, if the second consonant in $\mathrm{C}_{1} \mathrm{C}_{2}$ is an $r$, resolution is obtained by homorganic glide applied as in case (ii). Resolution by Glide -i-formation and vocalic epenthesis, as in Astypalaea (under 3.2.2 above), is excluded for two reasons. First, as Psaltis remarks, hiatus is in general avoided in the dialect not only within words by consonantal

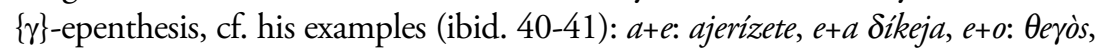
but also in sandhi (p. 38). Second, the position of epenthesis contradicts the immediately following third case of hiatus, avoidance in a -Cria sequence.

(iii) Suffix -tria:

The third case of hiatus is the suffix -tria. Psaltis (ibid. 57, 116) refers to an ending -tria used to form feminine nouns (corresponding to Ancient Greek 


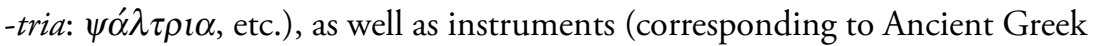

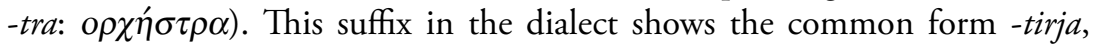
which he reasonably relates to tria $>$ tirja. ${ }^{18}$

$\begin{array}{llll}\text { feminine } & \text { lefkádirja } & \text { for } & \text { lefkádria } \\ \text { nouns : } & \text { fádrija } & & \text { ifádria } \\ & \text { ksástirja } & & \text { ksástria } \\ & \text { ráftirja } & & \text { ráftra } \\ \text { instrumentals: } & \text { patítirja } & \text { for } & \text { patítra } \\ & \text { mezítirja } & & \text { mezí日ra } \\ & \text { zumástirja } & & \text { zumástra }\end{array}$

Psaltis (p. 57) accounts for these forms by metathesis of $r$ (probably as pléx-tria $>$ plextrija $>$ plextirja), which he compares with other cases of $r$-metathesis as in (p. 57) olokirtinos for olokitrinos, stréro for stéryo. However, these cases of $r$-metathesis he mentions are sporadic examples in isolated words. Furthermore there is no reason to avoid $r$-loss, by metathesis, as proposed for Samothraki (cf. Topindzi 2006), since an $r V$-sequence is well accepted in the dialect. The question then is, what causes the metathesis in this suffix? Our proposal is interference from morphology, as shown below.

Similarities as well as differences with Samothraki are obvious. Instead of Topindzi's (2006) homorganic spreading and $i$-metathesis to avoid $r$-loss (and in Topindzi \& van Oostendorp 2009 by $r$-metathesis), Psaltis proposes $r$-metathesis, but without specifying a strategy for resolving the hiatus. Data with stress-shift in non-derived diagnostic words like tria, rriá, xria, krios etc., which would clearly indicate a $j$-epenthesis, are not given in Psaltis. However some indication that hiatus in these cases is resolved by homorganic glide formation comes from the morphology. Thus Psaltis mentions some derived verbal forms from krios such as krijóno, krijosa, krijómata $(1905: 93,40)$ and from xría: áxrija (p. 40).

Corresponding Samothraki forms are kirjós, kirjónu, xirjá, xirjázum, axirjastus, where the stress shift indicates the glide- $i$ strategy for hiatus resolution and the epenthetic vowel is in a position parallel to those of other cases of $\mathrm{CrileV}$ resolution in the dialect: cf. not only with the suffix -tria, but also with plural formations: Sákirja, alétirja etc. Such data show clearly that in Samothraki phonological similarity controls the output of Cri/eV hiatus.

\footnotetext{
${ }^{18}$ For the origin and influence of these endings to each other in different dialects see Chadzidakis (1905: 416).
} 
In contrast the different output of CriV in Saranda Ekklisies is not phonologically but morphologically defined. Cases with homorganic glide formation as well as cases with metathesis in -tria-suffixation show the same phonological make-up of the Cria sequence: cf. CCria: óstrija, or VCria: kuprijá with homorganic glide, vs. CCria: ksastirjá or VCria: patitrija, with metathesis.

We thus conclude that in Saranda Ekklisies there are two types of complementarity of the glide strategies for hiatus resolution:

a. Phonological complementarity between glide- $i$ formation for case i) above of $\mathrm{Ci}, \mathrm{CC}_{\text {non } \mathrm{r}} i \mathrm{~V}$ forms vs. homorganic glide formation for $(\mathrm{C} / \mathrm{V}) \mathrm{Cri} \mathrm{V}$ forms for case ii) above.

b. Morphological Complementarity with Metathesis $r i>$ ir for the suffix -tria in case iii) above, in morphological formations.

A question remains: what causes the isolated metathesis in this particular suffix? Our answer is the interference of morphology. The proposal is that a possible model for the $i$-metathesis is the corresponding masculine suffix -tis in an attempt to obtain similarity in their outputs raf-tis : raf-tirja.

We thus conclude that there is complementarity in this dialect, which, however, is morphologically justified.

\section{Conclusions}

This article has discussed cross-dialect ambiguities of epenthesis, restricted to a disyllabic hiatus domain. We made three points in this respect: first, we distinguished two types of consonantal epenthesis: a default $\{\gamma\}$-epenthesis giving $\mathrm{a}[\gamma / \mathrm{j}]$ output, versus a homorganic glide epenthesis with a [j] output. Second, we established a preferred position for vocalic epenthesis: it obtains either at the edges of morphemes (stem and affix), or stem-internally. And third, we defined complementarity of the hiatus-resolving strategies, areally, phonologically, or by the intervention of morphology.

\section{Acknowledgements}

Endless thanks for endless cooperation to co-editor of JGL Gaberell Drachman. We also especially thank co-editors Brian Joseph and Anna Roussou for support and help. 


\section{References}

Anagnostopoulos, Georgios. 1930. Peri tis en Hpeiro Bourmpianis kai ton peri autin komon [concerning the dialect of Vourbiani and the neighbouring villages]. ByzantinischNeugriechische Jahrbücher 8: 448-461.

Andriotis, Nikolaos. 1930. Peri tou Glossikou Idiomatos tis Imvrou [On the dialect of Imvros]. Athina 42: 146-187.

Andriotis, Nikolaos. 1939. De quelques faits phonétiques du dialecte de Samothrace. Archives of Thracian Laographic and Linguistic Thesaurus 6: 153-208.

Chadzidakis, Georgios. 1905. Mesaionika kai Nea Ellinika. [Mediaeval and Modern Greek]. Athens: P.D. Sakellariou (Bibliothiki Marasli).

Chadziioannou, Kyriakos. 1996 Grammatiki tis omiloumenis Kypriakis Dialektou. [Grammar of the Cypriot Dialect]. Leukosia: Tamasos.

Dieterich, Karl. 1905. Sprache und Volksüberlieferungen der Südlichen Sporaden im Vergleich mit denen der übrigen Inseln der Ägäischen Meeres. Wien: A. Holder.

Dosuna, Julian Méndez. 2002. Deconstructing "Height Dissimilation” in Modern Greek. Journal of Greek Linguistics 3: 83-115.

Drachman, Gabriel and Angeliki Malikouti-Drachman. 1996. Dissimilation in Cypriot Greek: Competing Analyses. Studies in Greek Linguistics 17: 57-71.

Drachman, Gaberell and Angeliki Malikouti-Drachman. 2008. On Paradigm-shift and Opacity in Cypriot Greek. Paper presented at Cyprus Conference, June 2008. Athens (to appear).

Heisenberg, A. 1921. Die Liquida P im Dialekt von Samothrake. In Honour of G. Chadzidakis, 89-99. Athens.

Karanastasis, Anastasios. 1958. To idioma tis Astypalaeas [The dialect of Astypalaea]. Lexikografikon Arxeion 8: 59-64.

Katsanis, Nikolaos. 1996. To Glossiko Idioma tis Samothrakis [The Dialect of Samothraki]. Thessaloniki: Municipality of Samothraki.

Kontosopoulos, Nikolaos. 1994. Dialecti kai Idiomata tis Neas Ellinikis [Dialects and sub-dialects of Modern Greek]. Athens: ekdosis Gregori.

Kretchmer, Paul. 1905. Der heutige Lesbische Dialekt, verglichen mit den übrigen Nordgriechischen Mundarten. Vienna: A. Holder.

Malikouti-Drachman, Angeliki. 2001. Opaque Interactions in Cypriot Greek. In Y. Agouraki et al. (eds) Proceedings of the 4th International Conference on Greek Linguistics. Nicosia, September 1999, 54-61. Thessaloniki: University Studio Press.

Malikouti-Drachman, Angeliki. 2006. A Pilgrimage for two: Remarks on phonological strength in Cypriot Greek. In M. Janse, B. D. Joseph and A. Ralli (eds). Proceedings of the Second International Conference of Modern Greek Dialects and Linguistic Theory, 27-41. Mytilene: University of Patras.

Malikouti-Drachman, Angeliki. 2008. Spontaneous Gemination and other Wonders in Greek dialects. In N. Lavidas, E. Nouchoutidou, M. Sionti (eds) Perspectives in Greek Linguistics, 65-81. Newcastle upon Tyne. Cambridge Scholars Publishing.

Malikouti-Drachman, Angeliki. 2009. Sto Metexmio Prosodias kai Morfologias: Martiries tis Ellinikis [On the edges of Prosody and Morphology: evidence from Modern Greek]. Studies in Greek Linguistics 29: 15-42.

Malikouti-Drachman, Angeliki and Gaberell Drachman. 2009. Metathesis or Epenthesis in Sanothraki Greek? Paper presented at the 30th Conference of the Linguistic Department of the Aristoteleio University of Thessaloniki, 2009. To appear in Studies in Greek Linguistics 30 . 
Menardos, Simos. 1969. Glossikai Meletai [Linguistic Studies]. Posthumous reprinting of his studies on the Cypriot dialect. Lefkosia: Center of Scientific Studies.

Morelli, Frida. 1999. The Phonotactics and Phonology of Obstruent Clusters in Optimality Theory. Ph.D. Dissertation. University of Maryland.

Newton, Brian. 1972. The Generative Interpretation of Dialect: a Study of Modern Phonology. Cambridge: Cambridge University Press.

Pandelides, Christos. 1929. Phonitiki ton Neoellinikon Idiomaton Kyprou, Dodekanisou kai Ikarias [Phonetics of the Modern Greek Dialects of Cyprus, Dodecanese and Ikaria]. En Athinais: P.D. Sakellariou. [reprinted in Elliniki Dialektologia, 2].

Psaltis, Stamatios. 1905. Thraikika i Meleti peri tou glossikou idiomatos tis poleos ton Saranta Ekklision. [Thracian, or study on the dialect of Saranta Ekklisies]. En Athinais: P.D. Sakellariou. Bibliothiki Marasli.

Revithiadou, Anthi, Marc van Oostendorp, Kalomira Nikolou, and M. Tiliopoulou. 2004/2006. Vowel harmony in contact-induced systems. The case of Asia Minor dialects of Greece. In M. Janse, B. D. Joseph and A. Ralli (eds). Proceedings of the Second International Conference of Modern Greek Dialects and Linguistic Theory, 350-366. Mytilene: Patras University.

Rosenthall, Samuel. 1997. Vowel/glide Alternation in a Theory of Constraint Interaction. New York and London: Garland Publishing [1994. Ph.D. Dissertation, University of Massachusetts, Amherst].

Symeonides, Charalampos P. 2006. Istoria tis Kypriakis Dialektou. [The History of the Cypriot Dialect]. Lefkosia: Kentro Meleton Ieras Monis Kikkou.

Topintzi, Nina. 2006. A (Not So) Paradoxical Instance of Compensatory Lengthening: Samothraki Greek and Theoretical Implications. Journal of Greek Linguistics 7: 71-119.

Topintzi, Nina and Marc van Oostendorp. 2009. Palatalization and Centralization in Samothraki Greek. Studies in Greek Linguistics 29: 385-399.

Tsopanakis, Agapitos. 1940. Essai sur la phonétique des parlers de Rhodes (Texte und Forschungen zur Byzantinisch- Neugriechischen Jahrbüchern 40). Athens: Verlag der ByzantinischNeugriechischen Jahrbücher. 